\title{
Melting features along the western Ryukyu slab edge (northeast Taiwan): Tomographic evidence
}

\author{
Jing-Yi Lin \\ Ifremer, Centre de Brest, Plouzané, France \\ Shu-Kun Hsu \\ Institute of Geophysics, National Central University, Chung-Li, Taiwan \\ Jean-Claude Sibuet \\ Ifremer, Centre de Brest, Plouzané, France
}

Received 25 June 2004; revised 30 September 2004; accepted 8 October 2004; published 4 December 2004.

[1] Behind the sedimentary Ryukyu arc lies the Okinawa Trough, whose termination is located at the tip of the Ilan plain (northern Taiwan), just above the Ryukyu slab edge. The present-day active volcanic front is located $80-100 \mathrm{~km}$ above the Ryukyu slab and extends from Japan to Kueishantao Island, an islet situated $10 \mathrm{~km}$ offshore the Ilan plain. Between December 1990 and May 1999, 3370 earthquakes recorded in northern Taiwan by 65 seismic land stations were used to determine the three-dimensional $V_{p}$ and $V_{s}$ velocity structures and $V_{p} / V_{s}$ ratios. A low $V_{s}$ but high $V_{p} / V_{s}$ sausage-like body, $\sim 30 \mathrm{~km}$ in diameter, lies within the Eurasian mantle wedge, on top of the western Ryukyu slab extremity, at depths ranging between 20 and $100 \mathrm{~km}$. We suggest that the $\mathrm{H}_{2} \mathrm{O}$-rich component formed by dehydration processes from subducting sediments, oceanic crust, and serpentinized mantle above the Ryukyu slab and along the vertical portion of the slab edge might explain the presence of the sausage-like body. A low $V_{s}$ but high $V_{p} / V_{s}$ channel rises obliquely from the sausage-like body at a depth of $40 \mathrm{~km}$ in direction of the andesitic Kueishantao Island. We propose that the $\mathrm{H}_{2} \mathrm{O}$-rich component and/or melt rise up from the sausage-like body and interfere with the Okinawa Trough back arc basin magmas formed in the upper mantle/lower crust. Then magmas propagate upward within the upper brittle crust through veins and/or narrow conduits. INDEX TERMS: 7218 Seismology: Lithosphere and upper mantle; 8110 Tectonophysics: Continental tectonics—general (0905); 8123 Tectonophysics: Dynamics, seismotectonics; 8180 Tectonophysics: Tomography; 8434 Volcanology: Magma migration; KEYWORDS: Ryukyu slab, Okinawa Trough, seismic tomography, melting features

Citation: Lin, J.-Y., S.-K. Hsu, and J.-C. Sibuet (2004), Melting features along the western Ryukyu slab edge (northeast Taiwan): Tomographic evidence, J. Geophys. Res., 109, B12402, doi:10.1029/2004JB003260.

\section{Introduction and Geological Setting}

[2] Most arc volcanic rocks are derived from melting of the mantle wedge induced by hydrous fluids released during dehydration reactions in the subducted oceanic lithosphere [Arculus, 1994; Gill, 1981]. Relatively primitive basalts, rhyolites, and andesites have been found in the middle and southern Okinawa Trough (OT) back arc basin [e.g., Shinjo et al., 1999], where is located the present-day active volcanic front (Figure 1). On the basis of velocity tomographic results under northeastern Japan, Wyss et al. [2001] have demonstrated that volcanoes of the volcanic front are linked to a source of magma and fluids originated at the top of the subducting slab and reaching the surface through an oblique mantle and crustal pathway. This observation suggests a strong relationship between

Copyright 2004 by the American Geophysical Union. 0148-0227/04/2004JB003260\$09.00 the generation of magmas in the OT and the subducting slab. The purpose of this paper is to define the $V_{p}, V_{s}$ velocity structures and the $V_{p} / V_{s}$ ratios in the area of the western termination of the Ryukyu slab and to provide tomographic images in order to characterize the geometry of melt and/or fluid flow near the slab edge and the magmatic pathway which results in the formation of the Kueishantao Island.

[3] Taiwan Island is located at the intersection of two converging systems: the Ryukyu subduction zone which results from the subduction of the Philippine Sea $(\mathrm{PH})$ plate beneath Eurasia (EU) and the Manila subduction zone which results from the subduction of EU beneath PH. In this complex geodynamical context, the Ryukyu subduction zone, which extends from Japan to Taiwan, terminates westward beneath northeastern Taiwan (Figure 1). Since early middle Miocene (15 Ma), the continuous oblique $\mathrm{N} 307^{\circ}$ subduction of the $\mathrm{PH}$ plate beneath EU with respect to the mean $\mathrm{N} 060^{\circ}$ direction of the Eurasian margin 


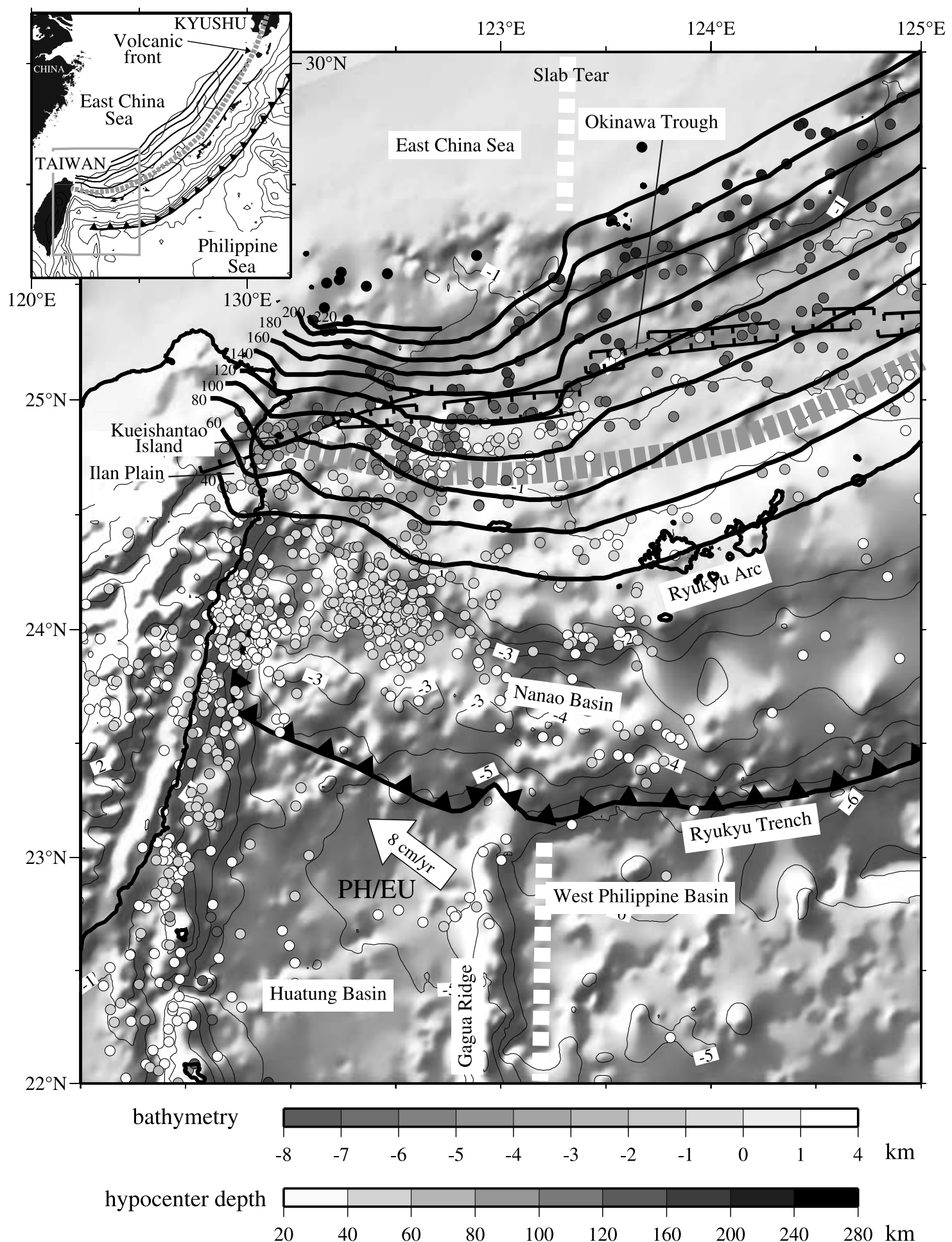

Figure 1. Shaded bathymetry and seismicity [Engdahl et al., 1998] in the northwestern corner of the Philippine Sea plate. Dots represent earthquake hypocenters. The black contour lines are depths of the Wadati-Benioff zone (adapted from Font et al. [1999] in the western part). Inset is a general map of the Ryukyu subduction zone with slab isobaths every $50 \mathrm{~km}$ [Sibuet et al., 1998]. The volcanic front (dashed gray line) is located $80-100 \mathrm{~km}$ above the slab. The locations of Ryukyu trench and Okinawa Trough normal faults are from Sibuet and Hsu [2004]. The arrow indicates the PH plate motion relative to EU [Yu et al., 1997]. 
involves a westward propagation of the Ryukyu slab with respect to EU at a mean velocity of about $4.5 \mathrm{~cm} / \mathrm{yr}$ [Sibuet et al., 2002]. On the basis of numerous available highquality earthquake locations and focal mechanisms in Taiwan [e.g., Kao and Chen, 1991; Kao et al., 1998], the Ryukyu slab geometry has been already determined [e.g., Font et al., 1999], but its western end is poorly defined. Earthquake data are always presented as a series of parallel vertical cross sections more or less parallel to the Ryukyu slab edge and do not clearly show the westward disappearance of slab earthquakes [Font et al., 1999; Kao and Rau, 1999; Tsai, 1986]. Similarly, previous tomographic studies have clearly imaged the Ryukyu slab under Taiwan [Lallemand et al., 2001; Rau and Wu, 1995; Roecker et al., 1987] but not precisely the western termination of the slab. However, the triangular shape of the southwestern OT and the location of its tip (western end of the Ilan Plain) just above the Ryukyu slab termination suggest that the overlying OT back arc basin simultaneously propagated westward at the same velocity than the Ryukyu slab [Sibuet and $\mathrm{Hsu}, 2004]$.

[4] The volcanic front (dashed gray line in Figure 1) extends from Japan to Taiwan. From Kyushu to Okinawa Island, it coincides with small subaerial active volcanoes located about $25 \mathrm{~km}$ west of the ancient volcanic arc. Southwest of Okinawa Island, it follows numerous seamounts associated with high-magnitude magnetic anomalies [Hsu et al., 2001], then the cross-back-arc volcanic trail, which consists of a cluster of about 70 seamounts located west of $123^{\circ} \mathrm{E}$ longitude, and finally ends $10 \mathrm{~km}$ offshore Taiwan at Kueishantao Island [Chung et al., 2000; Sibuet et al., 1998], an island located in the axis of the nascent OT. The volcanic front is located $80-100 \mathrm{~km}$ above the subducted slab. $80 \mathrm{~km}$ is the minimum slab depth required for the emplacement of arc magmatism [Gill, 1981; Tatsumi, 1986], explaining why the volcanic front is located within the OT, north of the Ryukyu nonvolcanic arc where only sedimentary islands outcrop. Rocks from the present-day volcanic front are predominantly andesites, although they range from basalts to rhyolites both in the northern Ryukyu arc [Daishi, 1992; Nakada, 1986] and in the southwestern OT [Chung et al., 2000; Shinjo, 1999] and andesites in Kueishantao Island [Chen et al., 1995; Chung et al., 2000]. In fact, the location of the volcanic front in the axis of the southwestern OT back arc basin favors the emplacement of back arc basin volcanic rocks with a large involvement of a subduction component [Shinjo, 1999].

[5] In the following sections, we will try to show how tomographic images, even if data are restricted to the western Ryukyu slab edge and Kueishantao Island, can provide useful images concerning the locations of magmas and fluids and their ascending pathways through the overlying EU mantle and crust.

\section{Velocity Structures Beneath Northeastern Taiwan}

\subsection{Methodology and Data}

[6] Between December 1990 and May 1999, 3370 earthquakes occurring north of $23.5^{\circ} \mathrm{N}$ were extracted from the Central Weather Bureau database (Figure 2). The selection of earthquakes is based on the following criteria: (1) Earthquakes must have occurred within the seismic recording net of stations; (2) their magnitude must be larger than 3.0 ; (3) $P$ arrivals must be recorded at least by 10 stations; and (4) earthquakes with more than four bad quality records (weight 4 in the sense of the "SIMUL 2000" program [Eberhart-Phillips, 1986, 1990; Thurber, 1983, 1993; Thurber and Eberhart-Phillips, 1999]) are removed. In other words, earthquakes whose events display time residuals larger than $50 \mathrm{~s}$ after the first time inversion were removed. The "flexible gridding" method [Thurber and Eberhart-Phillips, 1999] increases the fine-scale resolution and prevents an inhomogeneous ray path distribution. Different gridding space intervals were applied in function of the ray path density. In the volumes of high ray path density, the use of fine gridding interval increases the finescale resolution. In the regions of poor checkerboard test resolution, values of the slave grids (gray circles) are identical to values of the adjacent master grids (stars) (Figure 3). The spacings for master and slave nodes are 18 and $6 \mathrm{~km}$ respectively. In addition, the linkage of slave and master grids helps to recover a reliable smoothed structure in the volumes of low ray path distribution.

[7] A total of $83,107 P$ wave and 44,412 $S$ wave arrival times recorded by 65 seismic land stations were selected in this study. In the velocity model of Chen [1995], the island of Taiwan was divided in three areas (west, northeast, and southeast Taiwan). The average one-dimensional (1-D) model of the northeast area was used as the initial 1-D starting model in our inversion. The "SIMUL 2000" program was applied to inverse the $V_{p}, V_{s}$, and $V_{p} / V_{s}$ structures. A "pseudobending" synthetic ray path method was used to calculate travel times [Um and Thurber, 1987]. After parameter decomposition, a damped least squares technique was applied to inverse the $P$ and $S$ wave velocity structures. The ratios of 3-D $V_{p}$ and $V_{s}$ models to determine the 3-D $V_{p} / V_{s}$ structure can lead to severe artifacts in areas where $V_{s}$ is badly resolved [Eberhart-Phillips, 1990; Thurber, 1993]. Thus, instead of computing directly the $V_{p} / V_{s}$ structure from $V_{p}$ and $V_{s}$ values, we have used the $V_{p}$ and $V_{s}$ residual time arrivals to calculate the $V_{p} / V_{s}$ ratios. Tomographic results are displayed in percentage of variations with respect to the average value calculated at a given depth as proposed by Thurber and Eberhart-Phillips [1999].

[8] The resolution $\mathrm{R}$ is defined by the equation $\mathrm{m}^{\text {est }}=$ $\mathrm{Rm}^{\text {true }}$ given by Menke [1984] where $\mathrm{m}^{\mathrm{est}}$ is the estimated set of model parameters, $\mathrm{m}^{\text {true }}$ is the true but unknown set of model parameters, and $\mathrm{R}$ is the model resolution matrix. $\mathrm{m}^{\text {true }}$ is the solution of $\mathrm{G} \mathrm{m} \mathrm{m}^{\text {true }}=\mathrm{d}^{\text {obs }}$, where $\mathrm{G}$ is the data kernel in analogy with the theory of integral equations and $\mathrm{d}^{\text {obs }}$ are the arrival times. The model resolution matrix $\mathrm{R}$ shows how $\mathrm{m}^{\text {est }}$ is close from the true solution $\mathrm{m}^{\text {true }}$. The quality of resolution depends on the similarity between the model resolution matrix (R) and the identity function (I). If $\mathrm{R}=\mathrm{I}$, each model parameter is uniquely defined. The diagonal elements of the resolution matrix represent the resolvability of the model (resolution). When the diagonal elements are close to 1.0 , the estimated parameters $\left(\mathrm{m}^{\text {est }}\right)$ mostly correspond to the real data. According to the tradeoff curve established from the data variance and the model variance, the damping values were chosen as 45 for $V_{p}$ and 


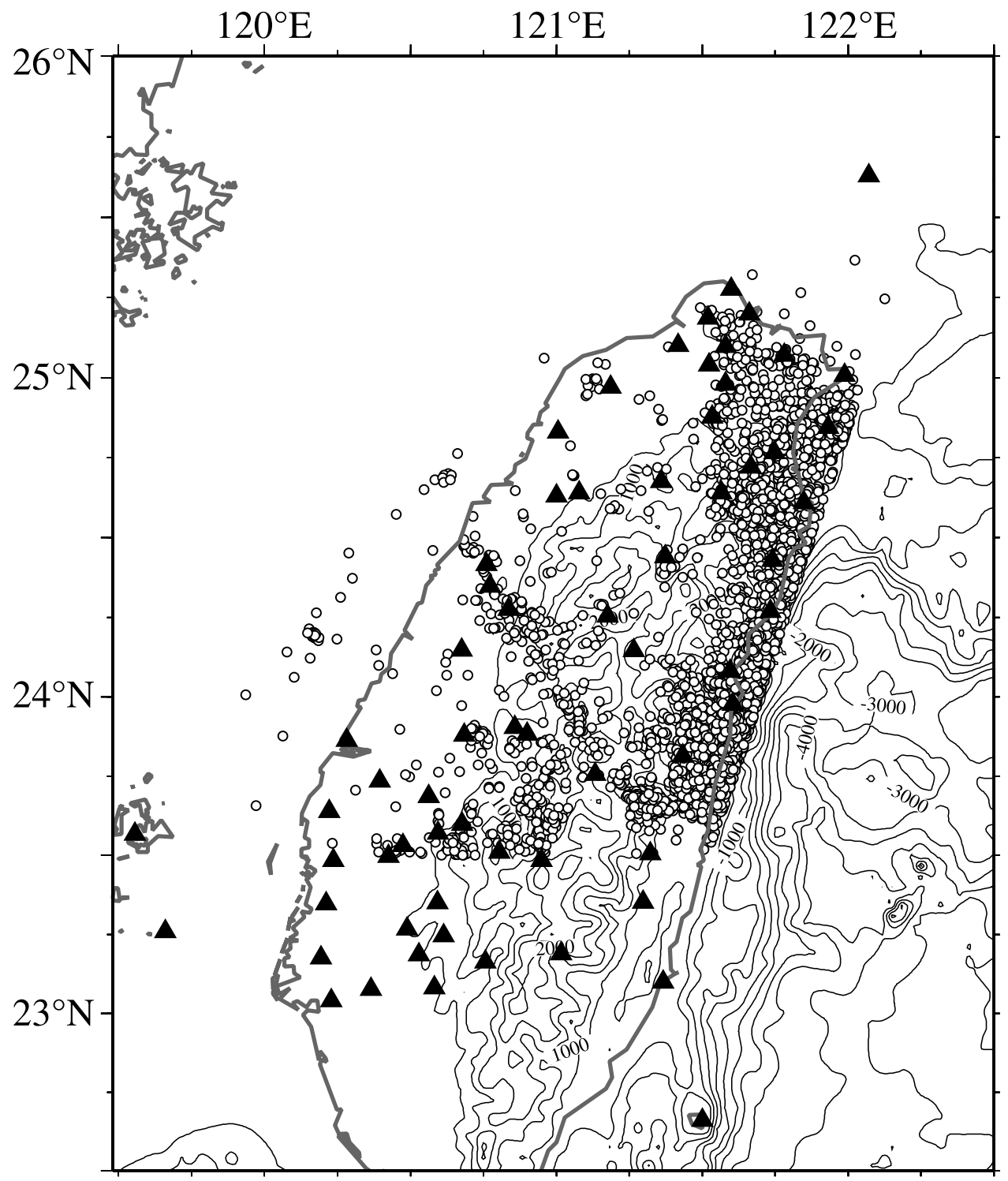

Figure 2. Location of seismic recording stations (triangles) and earthquakes (circles) used in this study.

as 40 for $V_{p} / V_{s}$ inversion in order to minimize the data and the model variances.

\subsection{Tomographic Inversion and Results}

[9] Figure 3 shows the results of $P$ waves checkerboard resolution tests. We assigned positive and negative velocity perturbations of $\pm 3 \%$ alternately to the grid nodes and calculated travel times for this model to produce synthetic data. The synthetic data were then inverted with an initial model of zero velocity perturbation. The results of $P$ waves checkerboard resolution tests are excellent in the eastern and northeastern portions of the data volume for shallow depths $(15$ to $60 \mathrm{~km})$, and also for larger depths but only in the restricted northeastern corner of the data volume. Figures 4 to 6 present $P$ and $S$ wave and $V_{p} / V_{s}$ ratio perturbation tomographic images for 12 depth slices ranging from 2 to $125 \mathrm{~km}$. Figure 7 shows, as an example, the $V_{p}$ data resolution, which is very similar to the $V_{p} / V_{s}$ data resolution (not shown here). $V_{p} / V_{s}$ values higher than 1.78 have been contoured in Figure 6 and transferred on the other figures. Except for shallow areas, the resolution is of good quality. In particular, the area of the Ryukyu slab edge is properly imaged from 7 to $125 \mathrm{~km}$ (Figure 7). The hypocenter relocation results show an average shift of $2.6 \mathrm{~km}$ in the horizontal plane and $0.4 \mathrm{~km}$ in depth, but this information is not used in this paper.

[10] On $V_{p} / V_{s}$ tomographic slices (Figure 6), a series of high-value anomalies located onshore, along the eastern coast of Taiwan progressively deepen to the north from 20 to $125 \mathrm{~km}$ deep, as highlighted by contoured $V_{p} / V_{s}$ values higher than 1.78. These high $V_{p} / V_{s}$ anomalies are located in the area of the western termination of the Ryukyu slab, just above the subducting slab. On $S$ wave tomographic images (Figure 5), the $V_{p} / V_{s}$ high-value anomalies are systematically associated with low $V_{s}$ perturbation anomalies. However, on $P$ wave tomographic images (Figure 4), such a correlation with low $V_{p}$ perturbation anomalies is not obvious.

[11] Two $V_{p}, V_{s}$ and $V_{p} / V_{s}$ vertical profiles (located on Figure 8) have been extracted (Figure 9). Profile 1 is located 

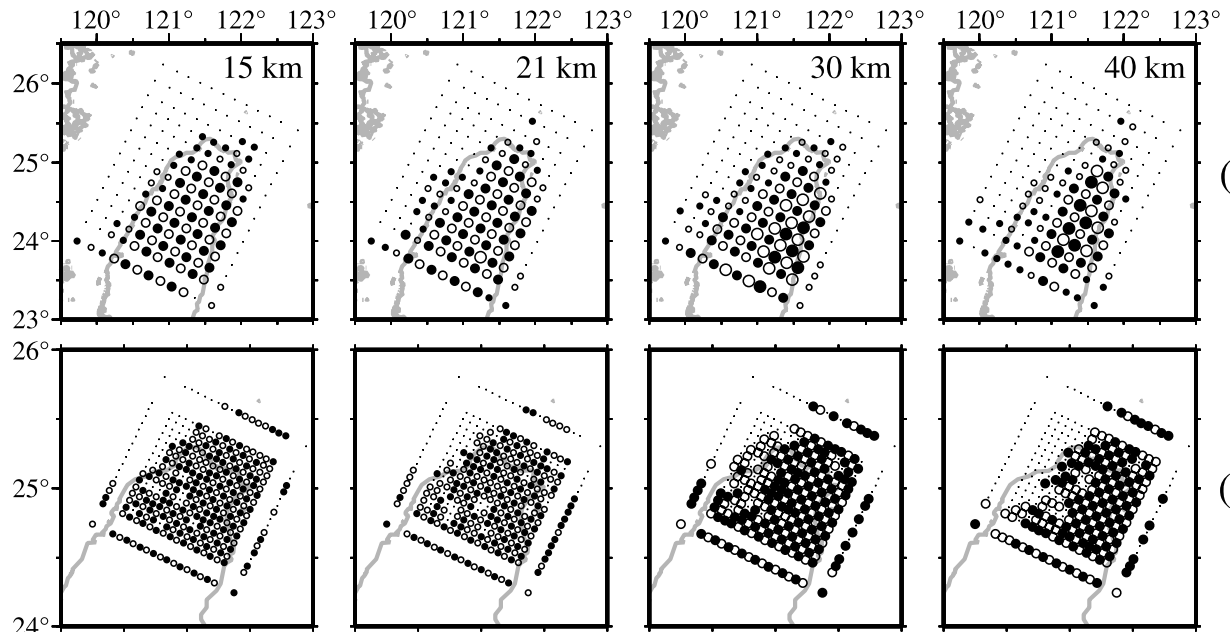

(b)
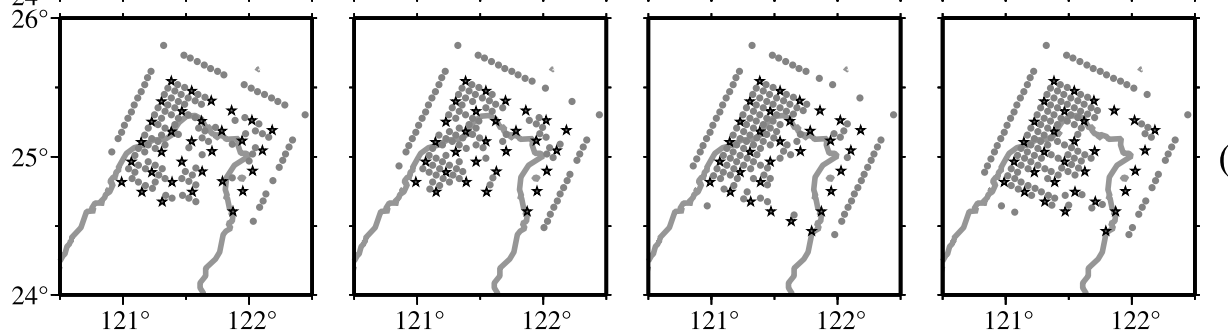

(c)
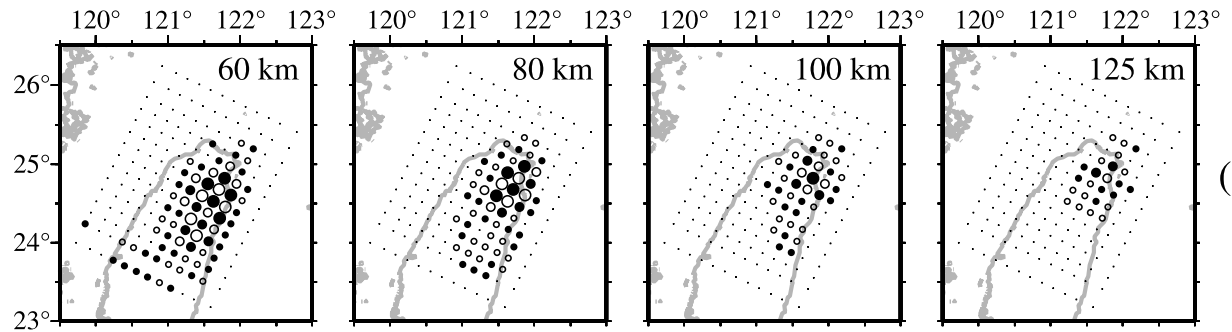

(a)
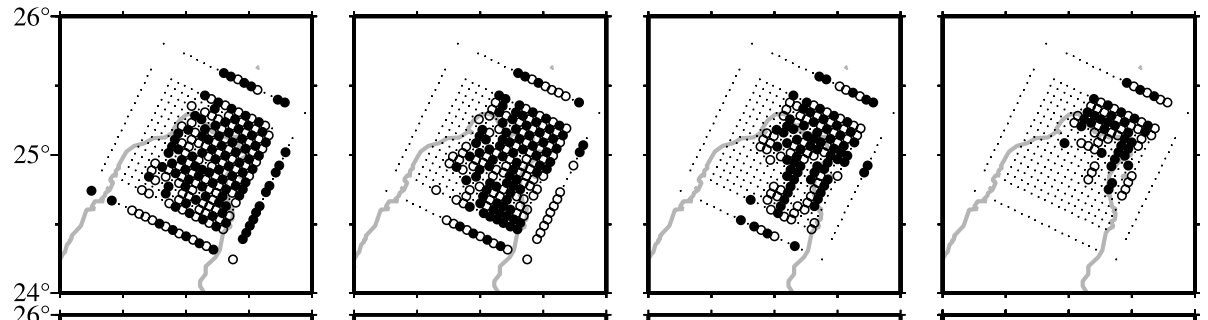

(b)
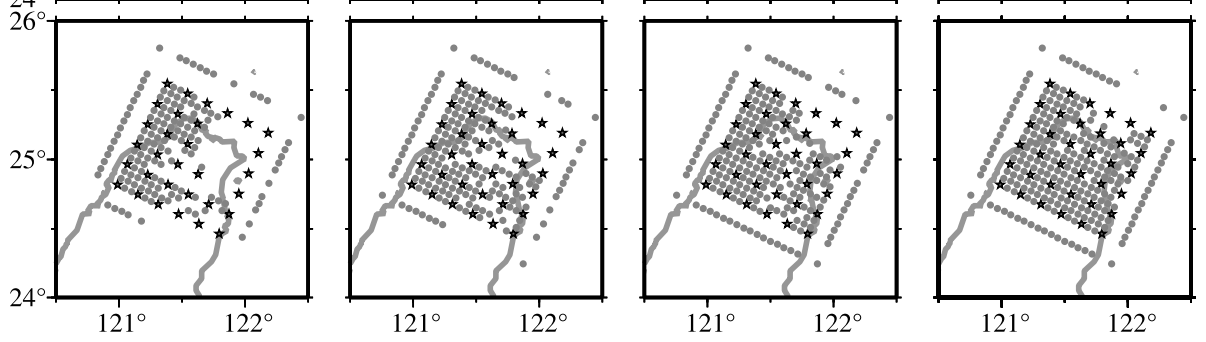

(c)

$$
\begin{array}{cccccccc}
\circ & \circ & \circ & \bullet & \bullet & \bullet & \bullet & \star \\
-3 \% & -2 \% & -1 \% & 0 \% & +1 \% & +2 \% & +3 \% & \text { Master grid }
\end{array}
$$

Figure 3. Results of checkerboard test resolution displayed for eight horizontal slices ranging from depths of 15 to $125 \mathrm{~km}$. (a) Gridding space of $18 \mathrm{~km}$; (b) gridding space of $6 \mathrm{~km}$; and (c) flexible gridding method applied in areas of poor checkerboard distribution. Slave and master grids are linked. 

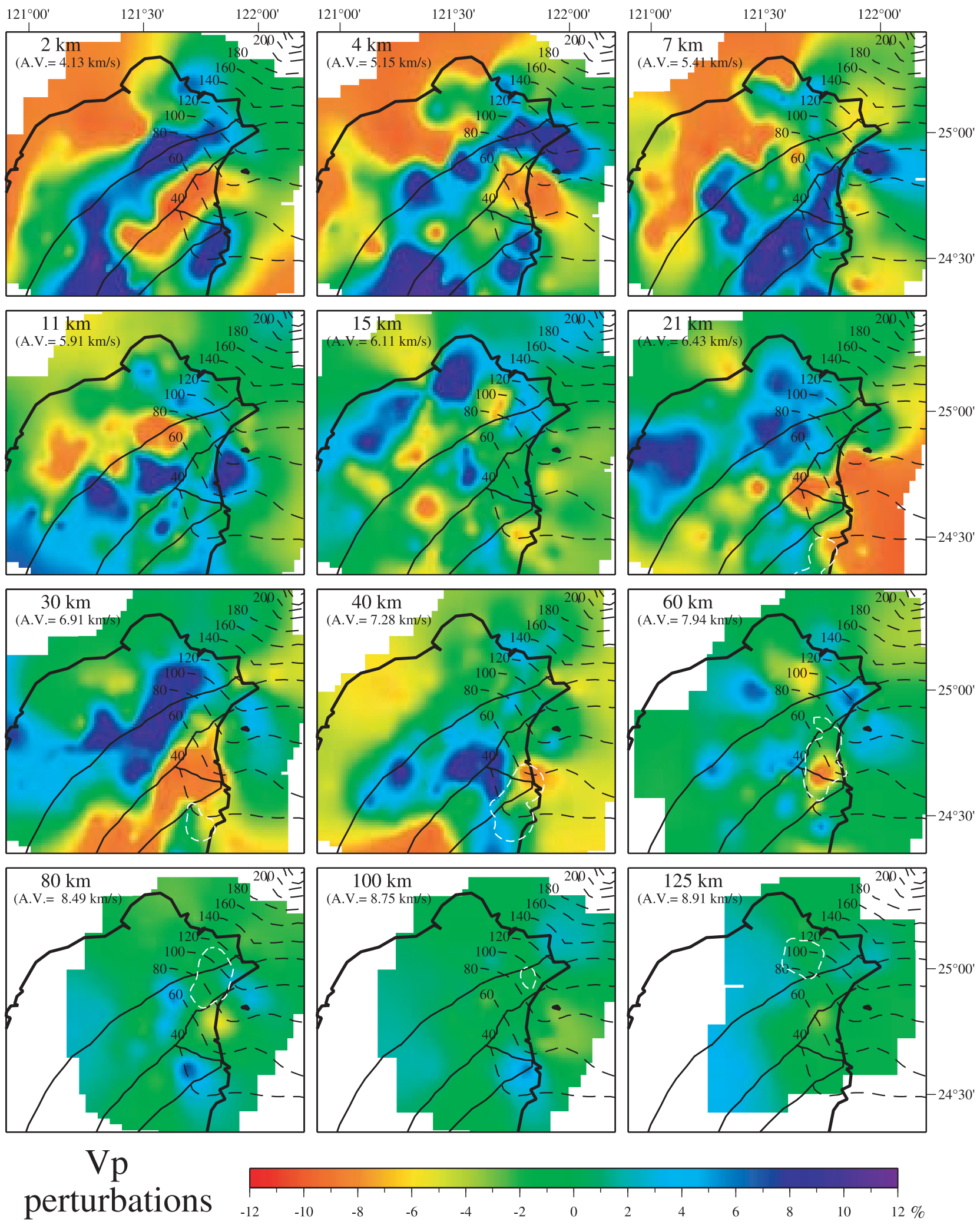

Figure 4. $V_{p}$ tomography results displayed for 12 horizontal slices from 2 to $125 \mathrm{~km}$. $V_{p}$ values are in percentages with respect to the average $P$ wave velocity at the depth of the slice. The black dashed lines represent the isobaths of the Wadati-Benioff zone [Font et al., 1999]. The white dashed lines represent the location of $V_{p} / V_{s}$ anomalies larger than 1.78 (pasted from Figure 6). 

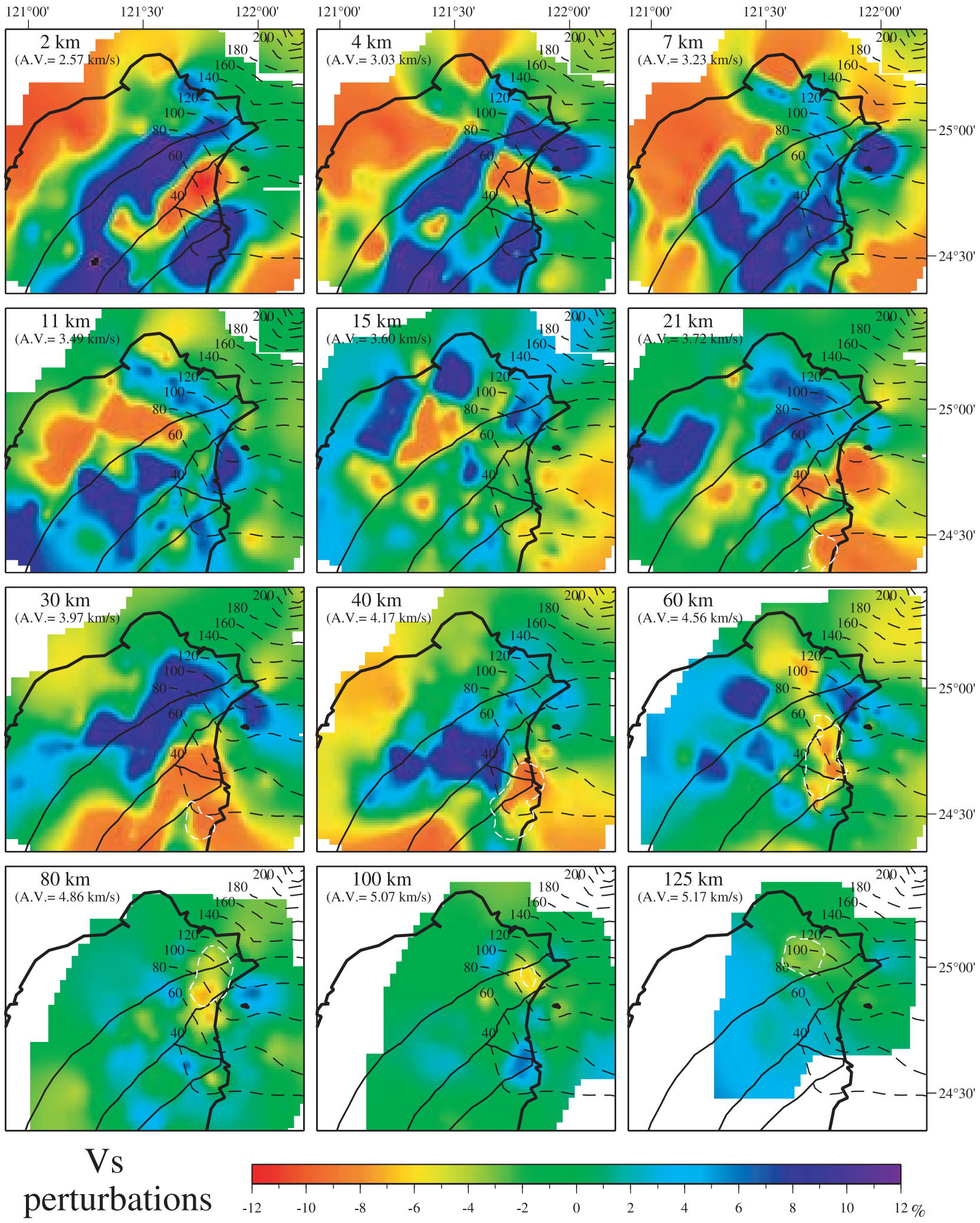

Figure 5. $V_{s}$ tomography results displayed for 12 horizontal slices from 2 to $125 \mathrm{~km}$. $V_{s}$ values are in percentages with respect to the average $S$ wave velocity at the depth of the slice. Legends are as in Figure 4. 

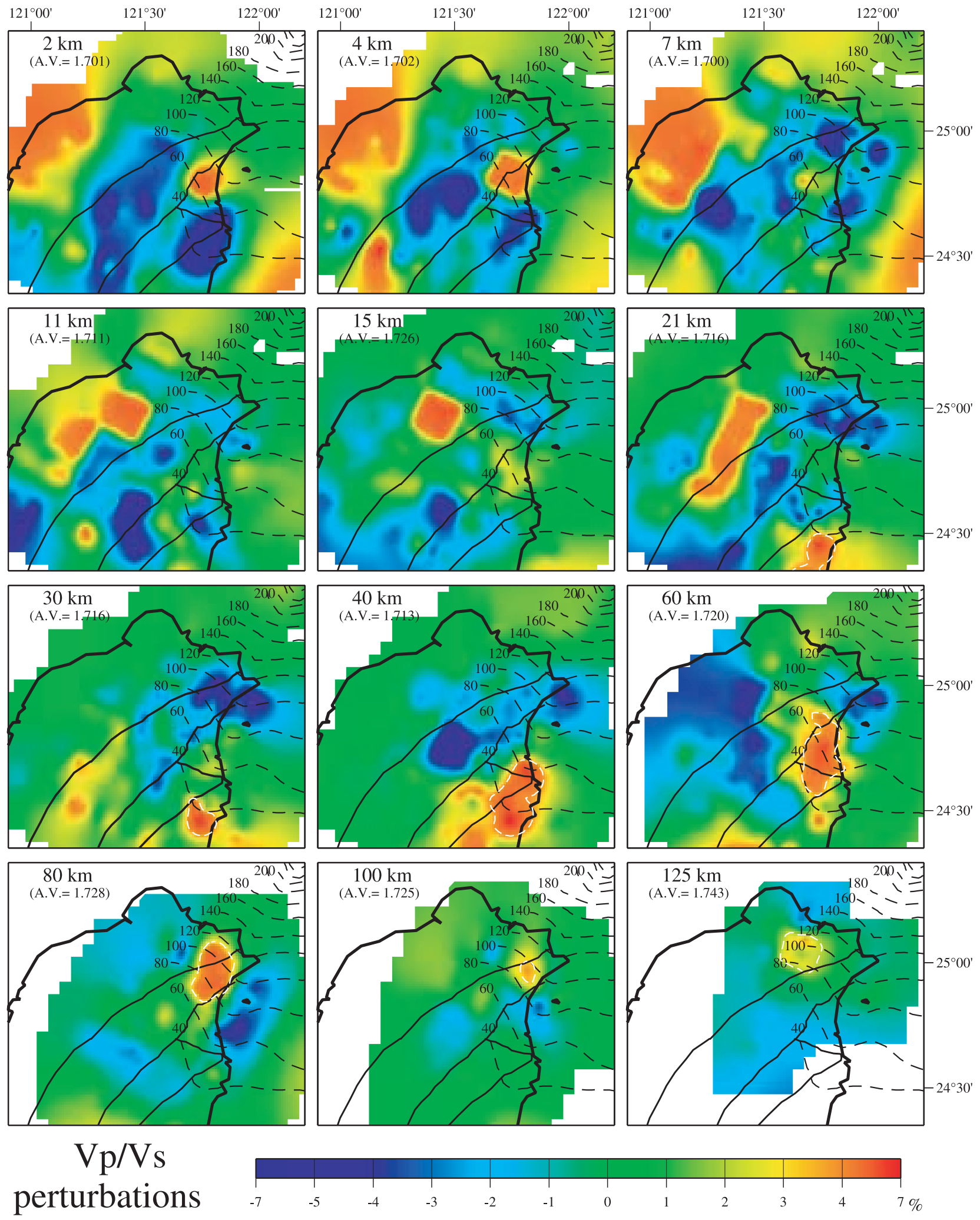

Figure 6. $V_{p} / V_{s}$ tomography results displayed for 12 horizontal slices from 2 to $125 \mathrm{~km}$. Legends as in Figure 4. The white dashed lines represent the location of $V_{p} / V_{s}$ anomalies larger than 1.78 , showing that the sausage-like body is properly imaged at depths larger than $21 \mathrm{~km}$. 

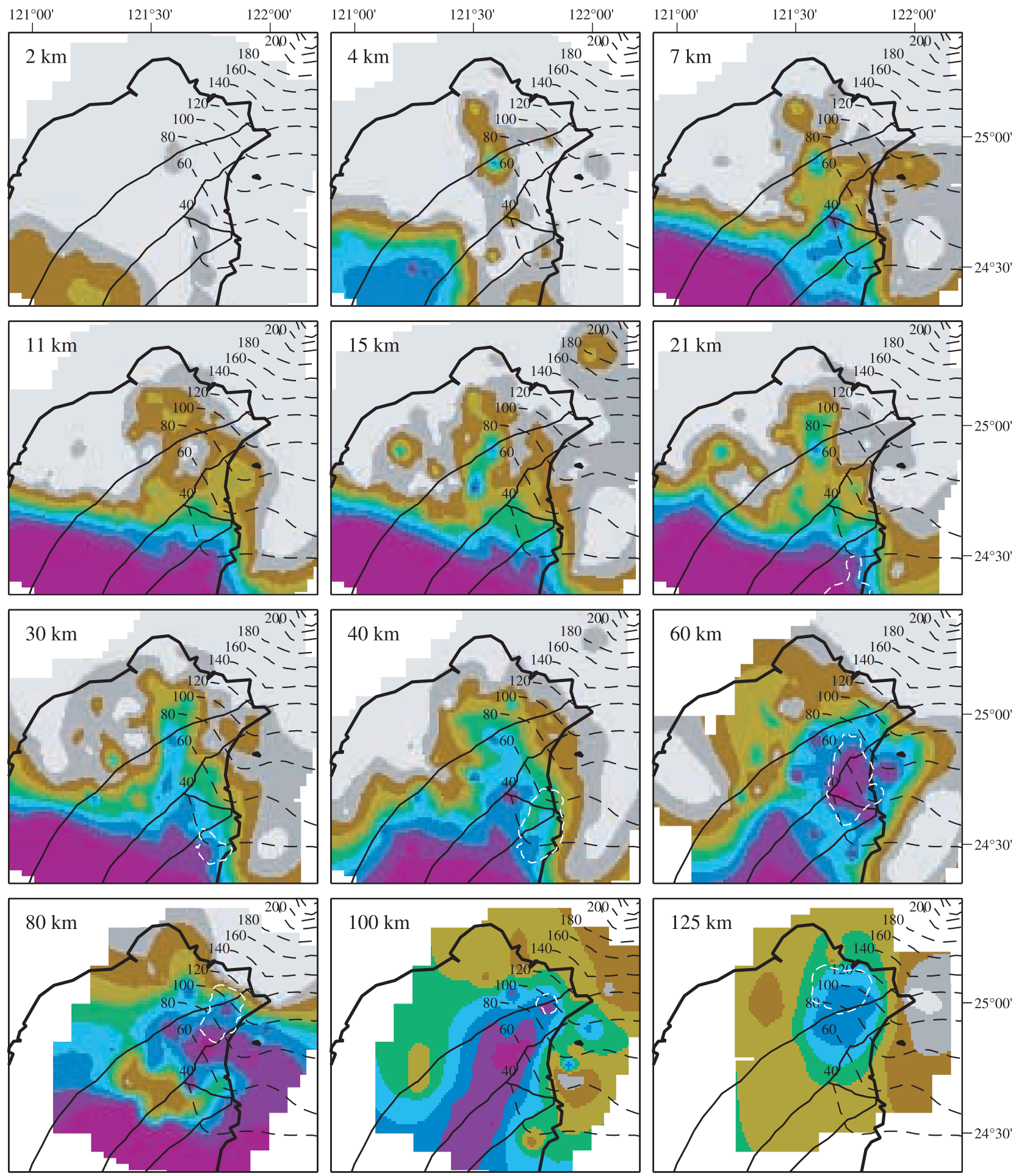

\section{$\mathrm{Vp}$ resolution}

0.0

Figure 7. $V_{p}$ resolution (diagonal elements of the resolution matrix) displayed for 12 horizontal slices from 2 to $125 \mathrm{~km}$. Legends are as in Figure 4.

on the EU continental crust, west of the Ryukyu slab termination, whereas profile 2 , located $20 \mathrm{~km}$ east of profile 1 , has been chosen along the trend of high $V_{p} / V_{s}$ anomalies. On profile 1, located about $10 \mathrm{~km}$ west of the Ryukyu slab edge, both the slab and the high $V_{p} / V_{s}$ velocity body have disappeared. Tomographic data obtained with less data (1197 earthquakes) and a similar analytical method by Rau and $W u$ [1995] show similar trends along profile 2 (Figure 9). On the two data sets, the continental crust about $35 \mathrm{~km}$ thick and the Ryukyu slab are well imaged. However, 


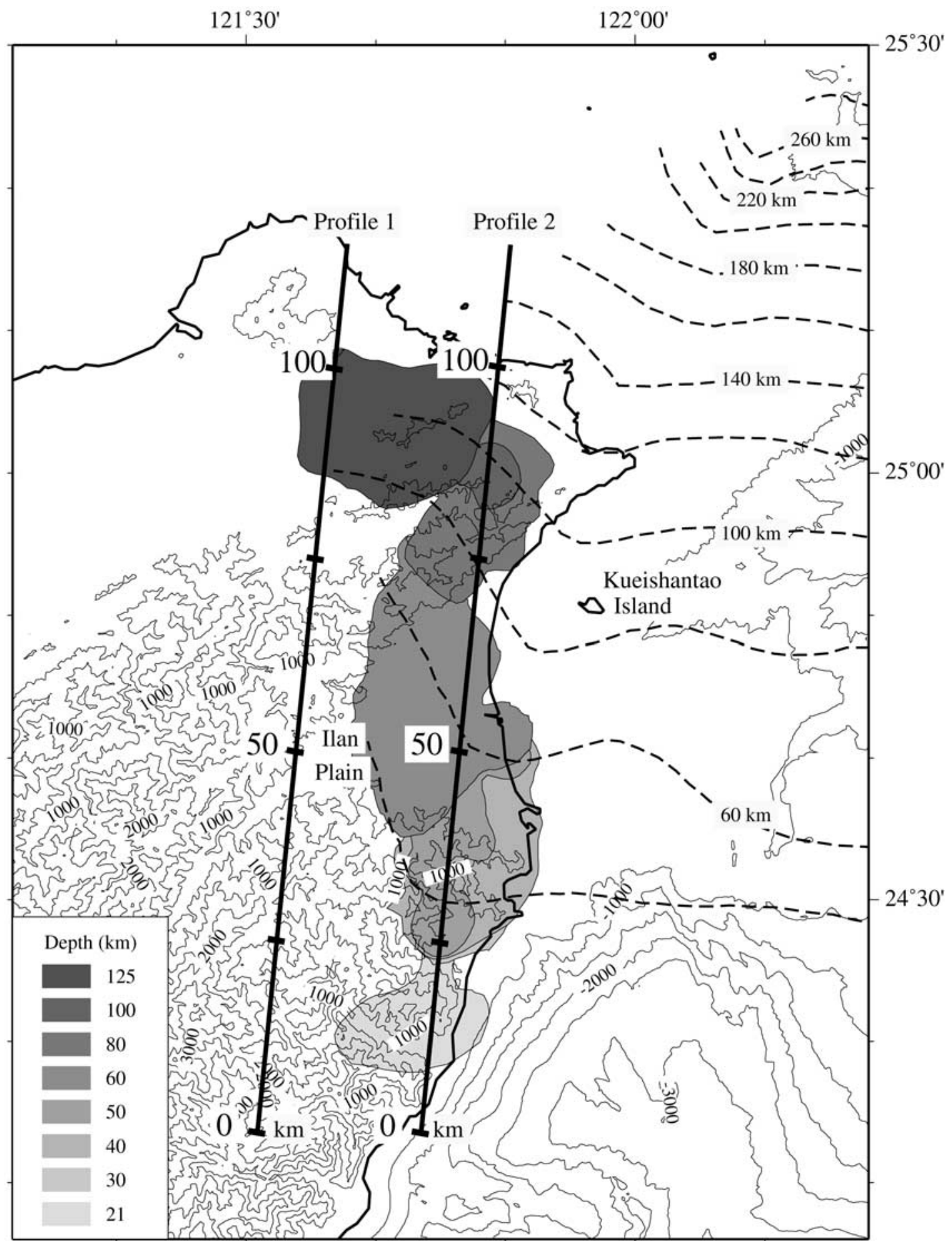

Figure 8. Geographical distribution of $V_{p} / V_{s}$ values higher than 1.78, extracted from slices of Figure 6 and ranging from $21 \mathrm{~km}$ (light gray) to $125 \mathrm{~km}$ (dark gray). Dashed lines are isobaths of the WadatiBenioff zone [Font et al., 1999]. The areas of high $V_{p} / V_{s}$ anomalies are located above the western edge of the Ryukyu slab. Tomographic profiles 1 and 2 are displayed in Figure 9.

the slab is better imaged in our data set because the tomographic gradient between 60 and $120 \mathrm{~km}$ corresponds to the earthquake epicenter envelope, which could be considered as an index of quality of our tomographic results. The high $V_{p} / V_{s}$ body is $30 \mathrm{~km}$ thick and is located above the Ryukyu slab (profile 2, Figure 9), within the EU continental crust and mantle. It continuously extends from a depth of 15 to $80 \mathrm{~km}$ for its top and 30 to $120 \mathrm{~km}$ for its floor. It was already but vaguely identified on Rau and $W u$ 's [1995] profile shown in Figure 9. The floor of this body corresponds exactly to the top of the Ryukyu slab, underlined by the upper envelope of earthquake locations. The horizontal width of the body is $\sim 30 \mathrm{~km}$ and remains constant throughout depth (Figure 8). Consequently, $V_{p} / V_{s}$ 


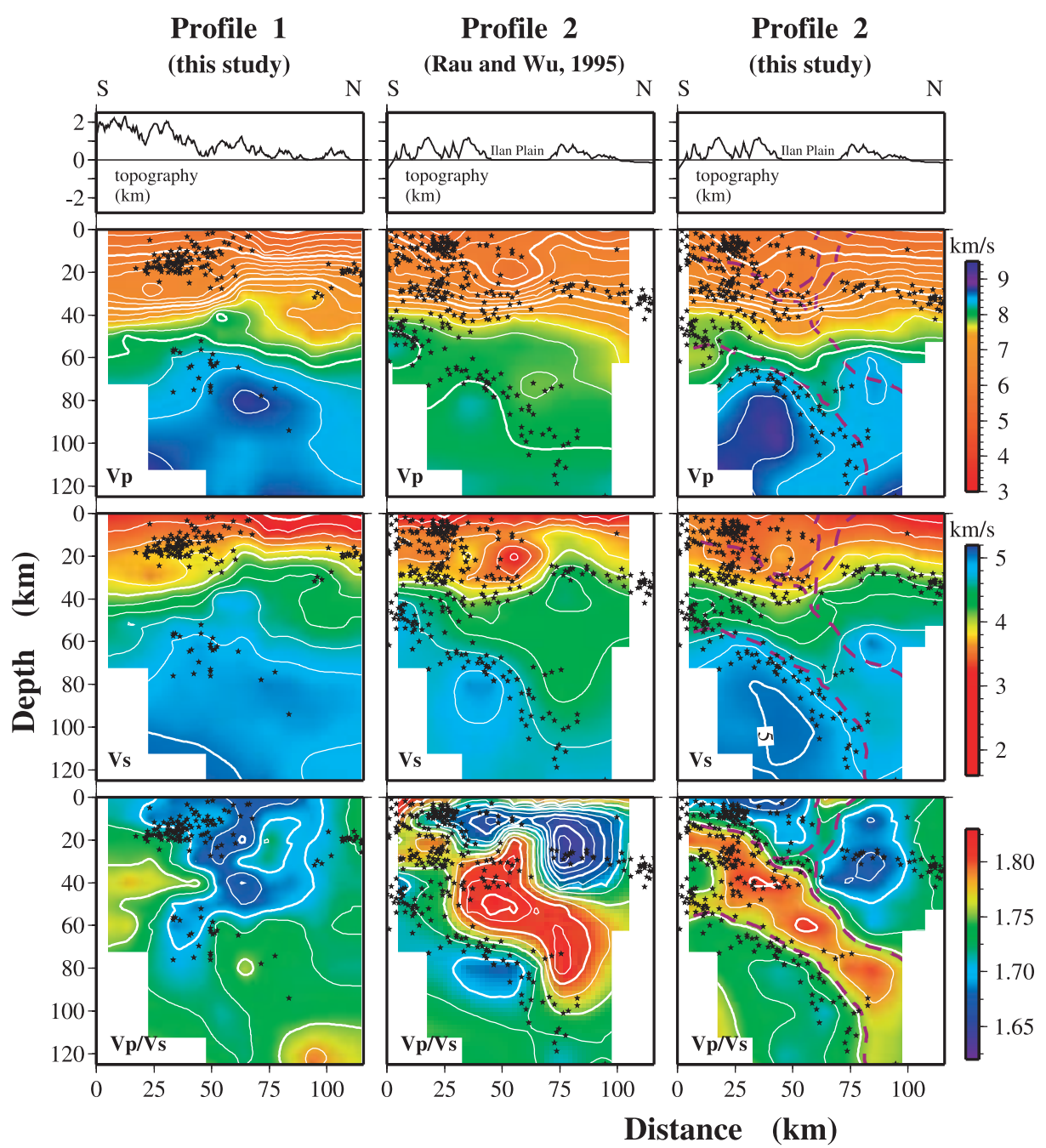

Profile 2

(this study)
Profile 2

(this study)
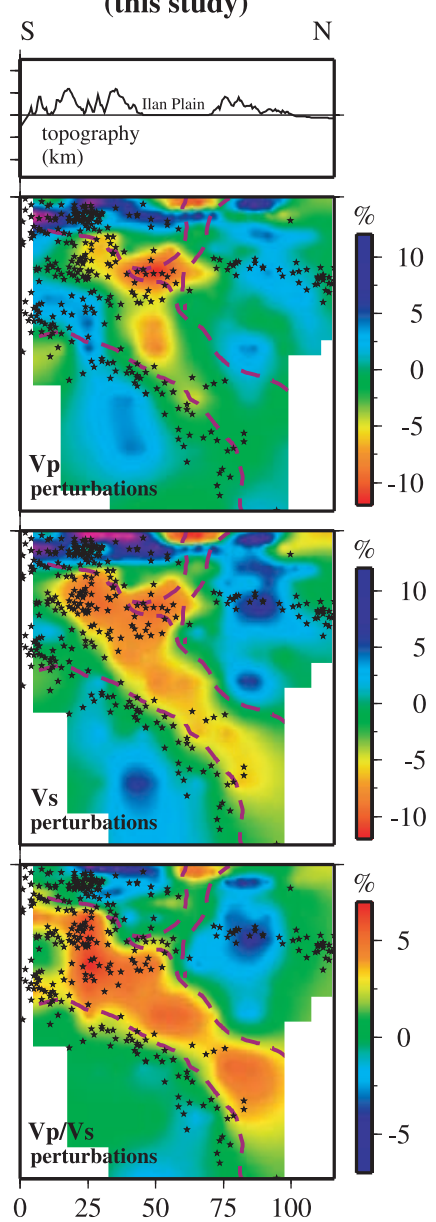

Figure 9. Tomographic results along profiles 1 and 2 located in Figure 8. (left) $V_{p}, V_{s}$, and $V_{p} / V_{s}$ values for profiles 1 and 2 . Contours every $0.2 \mathrm{~km} / \mathrm{s}$ for $V_{p}$ and $V_{s}$ and every 0.025 for the $V_{p} / V_{s}$ ratio. Stars are locations of earthquakes $(M>2.5)$ occurring in a $10 \mathrm{~km}$ wide stripe. Profile 1 is located on the EU continental crust, west of the Ryukyu slab edge. The few earthquakes located at depths of 50 to $80 \mathrm{~km}$ belong to the eastern part of the $10 \mathrm{~km}$ wide stripe. A comparison between results of Rau and Wu's [1995] model and ours shows the better resolution of our model and the good correspondence between the top of the Ryukyu slab and tomographic gradients. (right) $V_{p}, V_{s}$ and $V_{p} / V_{s}$ perturbation anomalies displayed along profile 2 in order to better image velocity anomalies of the sausage-like body and the feeding channel of Kueishantao Island. The high $V_{p} / V_{s}$ sausage-like body and channel are underlined by red dashed lines and then pasted in the other panels.

data show the presence of a continuous body $\sim 30 \mathrm{~km}$ wide and $30 \mathrm{~km}$ thick extending from mean depths of 20 to $100 \mathrm{~km}$ and located just above the edge of the Ryukyu slab. On profile 2 cross sections of $V_{s}$ perturbation anomalies, at depths deeper than $15 \mathrm{~km}$, this body corresponds exactly to a low-velocity structure, which extends down to the same depth than for the $V_{p} / V_{s}$ body (Figure 9).

[12] Figure 10 shows the 3-D geometry of the sausagelike body as well as a continuous and relatively high $V_{p} / V_{s}$ perturbation anomaly, which rises northerly in direction of the Ilan plain axis from a depth of $40 \mathrm{~km}$ to the subsurface. Then, the feature turns easterly at subsurface depths, along the back arc basin axis, in direction of Kueishantao Island. Low $V_{s}$ perturbation anomalies are also associated to this trend, except between depths ranging from about 7 to $13 \mathrm{~km}$ where higher $V_{p}$ and $V_{s}$ perturbation values are observed (Figure 9). The presence of an oblique feature reaching Kueishantao Island through the mantle wedge confirms that the magmatic origin of Kueishantao andesites is linked to the slab itself and that fluids and/or melt rise along an inclined path as demonstrated by Wyss et al. [2001] for arc volcanoes in northern Japan.

[13] To summarize, we have identified two continuous bodies characterized by high $V_{p} / V_{s}$ and low $V_{s}$ : (1) one with a sausage-like shape, $\sim 30 \mathrm{~km}$ in diameter and located within the EU mantle wedge, on top of the western Ryukyu slab termination, between depths of 20 and $100 \mathrm{~km}$, and (2) the other one rising northeastward and upward from the sausage-like body from a depth of $40 \mathrm{~km}$ in direction of Kueishantao Island. However, high $V_{p}$ and $V_{s}$ interrupting 


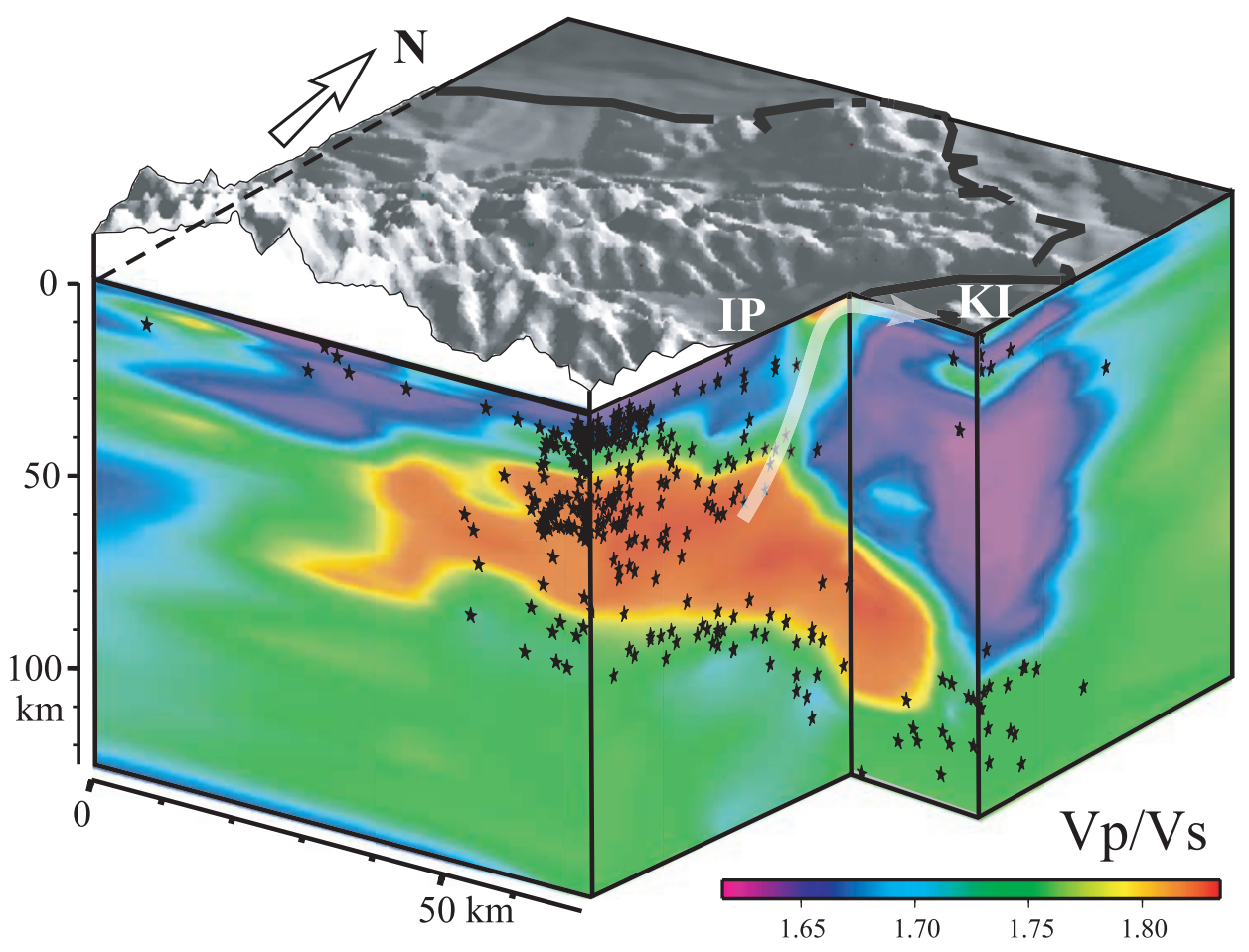

Figure 10. A 3-D block diagram showing cross sections of $V_{p} / V_{s}$ ratios. The high $V_{p} / V_{s}$ sausage-like body is cut along its axis (corresponding to profile 2 located in Figure 8). A high $V_{p} / V_{s}$ channel rises obliquely (white arrow) from the sausage-like body from a depth of $40 \mathrm{~km}$ in direction of the andesitic Kueishantao Island (KI). IP, Ilan Plain. Stars are earthquake locations. Shaded 3-D topography is extracted from Liu et al. [1998].

bodies are observed between depths of about 7 to $13 \mathrm{~km}$ as also noticed beneath the Japanese arc volcanoes [Nakajima et al., 2001b].

\subsection{Interpretation and Tectonic Implications}

[14] Magmatism associated with subducting plate edges or slab tears has been reported several times. Abrupt cutoffs of the deep seismicity offshore Sicily [Frepoli et al., 1996] give the location of the southern edge of the Ionian subducting lithosphere. Above the slab edge, a few volcanic edifices are spanning from the Etna (Sicily), located a few tens $\mathrm{km}$ above the slab edge, to Ustica Island located $400 \mathrm{~km}$ above the slab edge. They are characterized by an OIB-type activity which displays a peculiar geochemistry compatible with a slight mantle source contamination from subduction-related fluids [Beccaluva et al., 1982; Marani and Tra, 2002], allowing Marani and Tra [2002] to suggest the existence of upwelling asthenospheric flow above the slab edge.

[15] High-resolution 3-D tomographic images obtained in northern Honshu (Japan) show that low $V_{p}$, low $V_{s}$ and high $V_{p} / V_{s}$ are distributed in the upper mantle and crust along the volcanic front, with large crustal anomalies beneath individual volcanoes [Nakajima et al., 2001a, 2001b]. These anomalies rise from the top of the subducting slab (here at a depth of $150 \mathrm{~km}$ ) along inclined mantle paths to the volcanoes, except between 8 and $18 \mathrm{~km}$ where a zone of high $V_{p}$ is observed. Wyss et al. [2001] suggest that the inclined paths are associated with positive thermal anomalies and follow the expected mantle flow trajectories in the wedge located above the slab [Tamura et al., 2002].
[16] Watanabe [1993] shows that the melt fluid fraction significantly decreases $V_{p}$ and $V_{s}$ velocities; on the contrary, the effect of seawater contributes to the $V_{p}$ decrease but does not have any effect on $V_{s}$. Nakajima et al. [2001b] and Takei [2002] also calculated $V_{p}, V_{s}$, and $V_{p} / V_{s}$ variations when cracks in matrix are filled with $\mathrm{H}_{2} \mathrm{O}$ or melt. They conclude that low $V_{p}$, low $V_{s}$, and high $V_{p} / V_{s}$ in the lower crust and upper mantle are caused by partial melting and an $\mathrm{H}_{2} \mathrm{O}$-rich component because of a need of a too small aspect ratio of cracks in this later case.

[17] What physical mechanism could explain the existence of the continuous sausage-like body from 20 to $100 \mathrm{~km}$ depth above the Ryukyu slab edge? The continuous $8 \mathrm{~cm} / \mathrm{yr}$ subduction velocity of the Ryukyu slab in the $\mathrm{N} 307^{\circ}$ direction with respect to the EU lithosphere could generate some localized heating by friction of the two plates along the western vertical edge of the slab. However, Rüpke et al. [2004] suggest that shear stresses and shear heating, though largely unconstrained, are weak at the boundary between the slab and the adjacent mantle and lithosphere. Thus friction heating might be negligible. If the $800^{\circ} \mathrm{C}$ minimum required temperature to generate some melt occurs at depths larger than $80 \mathrm{~km}$, a slight increase in temperature would not significantly shallow the production of melt. It is thus impossible to explain by friction heating the extension of the sausage-like body up to $20 \mathrm{~km}$. Therefore a general mechanism, as an upward migration of fluids generated by deep dehydration, might exist to account for the fluid enrichment. Fluid release occurs above the slabs at depths $<20 \mathrm{~km}$ from subducting sedi- 


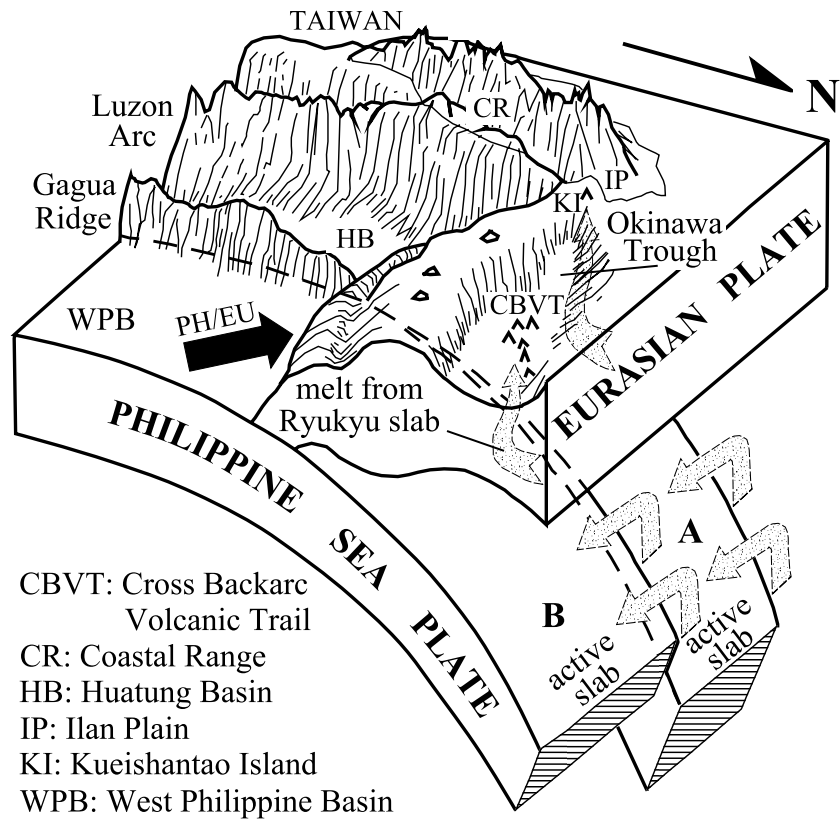

Figure 11. Diagram showing the slab tear occurring along the northern prolongation of Gagua Ridge, in the northwestern corner of the Philippine Sea plate. Stippled arrows indicate fluid-migrating pathways around the slab edges (between A and B and East of A). Contorted stippled arrows give an indication of the oblique fluid and melt pathways to the cross-back-arc volcanic trail (CBVT) and Kueishantao Island. The arrow shows the direction of the Philippine Sea plate motion relative to the Eurasian plate [Yu et al., 1997].

ments, at intermediate depths $(20-100 \mathrm{~km})$ from sediments and oceanic crust and at depths $>100 \mathrm{~km}$ from oceanic crust and serpentinized mantle [Rüpke et al., 2004]. Hacker et al. [2003] argue that intermediate depth earthquakes only occur where hydrous minerals are predicted to be present, implying a causal link between dehydration reactions and seismicity. The slab seismicity being more developed beneath the sausage-like body than along the rest of the slab [Kao et al., 2000], it suggests that an excess of the $\mathrm{H}_{2} \mathrm{O}$-rich component might be expected at the slab border and released along the vertical edge of the Ryukyu slab. Another possibility would be the upwelling of hot underlying $\mathrm{PH}$ lithospheric mantle around the Ryukyu slab edge due to mantle flow initiated within the ductile $\mathrm{PH}$ mantle by the westward PH motion with respect to EU.

[18] To summarize, we suggest that the $\mathrm{H}_{2} \mathrm{O}$-rich component and/or melt would be conveyed around the edge of the slab to form the sausage-like body located above the Ryukyu slab edge. Then the upward migrating $\mathrm{H}_{2} \mathrm{O}$-rich component derived from the sausage-like body might interact with the overlying EU lithosphere and enhance the generation of magmas located in the EU upper mantle/lower crust [Stolper and Newman, 1994], in the axis of the OT back arc basin.

[19] High-Mg (5\%) andesites have been recovered in Kueishantao Island [Chen et al., 1995; Chung et al., 2000]. Following Kelemen [1995] and Shinjo [1999], they might result from the reaction between EU mantle peridotite and the ascending liquid originated from the sausage-like body. For the first time, we have imaged that the feeding of a volcano seems to be directly connected to the $\mathrm{H}_{2} \mathrm{O}$-rich component and/or melt produced at the slab edge. The location of Kueishantao Island in the OT axis, even if back arc basin extension started there very recently $(<1 \mathrm{Ma})$ [Sibuet and Hsu, 2004] and is considerably reduced close to the OT termination, would favor the ascent of basaltic magma formed in the lower crust and/or upper mantle and already contaminated by the deep $\mathrm{H}_{2} \mathrm{O}$-rich component. Magmas would rise up along upper crustal normal faults developed within the back arc basin. Kueishantao andesites have very high ${ }^{87} \mathrm{Sr} /{ }^{86} \mathrm{Sr}$ and low ${ }^{143} \mathrm{Nd} /{ }^{144} \mathrm{Nd}$, which lead Chen et al. [1995] to propose that the Kueishantao magmas were substantially contaminated by the upper crust. As the most recent Kueishantao andesites erupted recently (8000 years) and hydrothermal activity is observed today on Kueishantao Island [Lee et al., 1998], the feeding channel is probably still active along the continuous low $V_{s}$ and high $V_{p} / V_{s}$ channel. Yet, the high $V_{p}$ and high $V_{s}$ perturbation anomalies from about 7 to $13 \mathrm{~km}$ might suggest that the $\mathrm{H}_{2} \mathrm{O}$-rich component and/or melt are restricted to depths larger than $13 \mathrm{~km}$ and only reach lower crustal levels. We also suggest that magmas propagate upward and eastward within the upper brittle crust through magmatic veins and/or narrow magma conduits because the crust of the back arc basin thins and is more tectonized eastward.

[20] Such a model is illustrated in the sketch of Figure 11. We suggest that the same mechanism also applies for the Ryukyu slab tear located along the $123.3^{\circ} \mathrm{E}$ meridian (Figure 1). A large cluster of volcanoes, called the crossback-arc volcanic trail (CBVT) [Sibuet et al., 1998] consists of basalts, rhyolites, and andesites. It is located in the axial part of the southern OT, at $123^{\circ} \mathrm{E}$ longitude and seems to be linked obliquely with the slab tear. We suggest that an excess of $\mathrm{H}_{2} \mathrm{O}$-rich component and/or melt might be formed at the slab tear and might increase the melt flux [Lin et al., 2004], involving the same process than for the sausage-like body. Both are conveyed obliquely in direction of the uppermost mantle and lower crust CBVT magmas. From there, after geochemical interactions with the $\mathrm{H}_{2} \mathrm{O}$-rich component coming from below, basaltic magmas rise up along normal back arc basin faults, in the CBVT area.

\section{Conclusions}

[21] The main conclusions of this study are as follows:

[22] 1.3370 earthquakes recorded in northern Taiwan by 65 seismic land stations between December 1990 and May 1999 were extracted from the database of the Central Weather Bureau in Taiwan. The 3-D $V_{p}$ and $V_{s}$ velocity structures and $V_{p} / V_{s}$ ratios were determined by inversion of $P$ wave arrivals and $P-S$ arrival residuals by using a "pseudobending" ray path method. A low $V_{s}$ but high $V_{p} / V_{s}$ sausage-like body was identified above the western extremity of the Ryukyu slab, from depths ranging from 20 to $100 \mathrm{~km}$. This sausage-like body, identified for the first time in this type of environment, is $30 \mathrm{~km}$ wide and $30 \mathrm{~km}$ thick. We suggest that the $\mathrm{H}_{2} \mathrm{O}$-rich component formed by dehydration processes from subducting sediments, oceanic crust and serpentinized mantle above the Ryukyu slab and along the vertical portion of the slab edge might explain the presence of the sausage-like body.

[23] 2. A low $V_{s}$ but high $V_{p} / V_{s}$ channel rises obliquely from the sausage-like body at a depth of $40 \mathrm{~km}$ in direction 
of the andesitic Kueishantao Island. The presence of high $V_{p}$ and high $V_{s}$ perturbation values from about 7 to $13 \mathrm{~km}$ might suggest that the $\mathrm{H}_{2} \mathrm{O}$-rich component and melt are restricted to depths larger than $13 \mathrm{~km}$ and only reach lower crustal levels. We propose that the $\mathrm{H}_{2} \mathrm{O}$-rich component and melt rise up from the sausage-like body and interfere with the OT back arc basin magmas formed in the upper mantle/ lower crust. Then, magmas propagate upward within the upper brittle crust through veins and/or narrow conduits not imaged in our tomographic results. The high-Mg andesites are likely to be the product of reaction between EU mantle peridotite and the ascending liquid originated from the sausage-like body.

[24] 3. A similar mechanism might explain the presence of an excess amount of basaltic and rhyolitic volcanoes located above the Ryukyu slab tear located at $123.3^{\circ} \mathrm{E}$ longitude.

[25] Acknowledgments. The GMT software package was used to draw some of the figures [Wessel and Smith, 1991]. This work is part of an ongoing cooperative project between France and Taiwan encouraged and supported by the French Institute of Taipei and by the National Science Council, Taiwan. Constructive discussions with S.-L. Chung, L. Ciron, E. Debayle, L. Dosso, S. Lallemand, C.-S. Liu, R. Maury, W. Roest, and R. Shinjo are acknowledged. We also acknowledge the very constructive reviews of G. Abers, A. Hasegawa, H. Kao, and C.-S. Lee.

\section{References}

Arculus, R. J. (1994), Aspects of magma genesis in arcs, Lithos, 33, 189208

Beccaluva, L., P. L. Rossi, and G. Serri (1982), Neogene to Recent volcanism of the southern Tyrrhenian-Sicilian area: Implications for the geodynamic evolution of the Calabrian arc, Earth Evol. Sci., 3, 222-238.

Chen, C. H., T. Lee, Y. N. Hsieh, C.-H. Chen, and W. Y. Hsu (1995), Magmatism at the onset of back arc basin spreading in Okinawa Trough, J. Volcanol. Geotherm. Res., 69, 313-322.

Chen, Y. L. (1995), Three-dimensional velocity structure and kinematics analysis in Taiwan area (in Chinese with English abstract), Master thesis, Natl. Cent. Univ., Chung-Li, Taiwan.

Chung, S.-L., S.-L. Wang, R. Shinjo, C.-S. Lee, and C.-H. Cheng (2000), Initiation of arc magmatism in an embryonic continental rifting zone of the southernmost part of Okinawa Trough, Terra Nova, 12, 225-230.

Daishi, M. (1992), Cenozoic volcanic activities and rocks from the Ryukyu Islands, in Commemorative Papers for Professor Yukio Matsumoto, pp. 49-60, Yamaguchi Univ. Press, Yamaguchi, Japan.

Eberhart-Phillips, D. (1986), Three-dimensional velocity structure in northern California Coast Range from inversion of local earthquake arrival times, Bull. Seismol. Soc. Am., 76, 1025-1052.

Eberhart-Phillips, D. (1990), Three-dimensional $P$ and $S$ velocity structure in the Coalinga region, California, J. Geophys. Res., 95, 15,343-15,363.

Engdahl, E. R., R. D. Van der Hilst, and R. P. Buland (1998), Global teleseismic earthquake relocation with improved travel times and procedures for depth determination, Bull. Seismol. Soc. Am., 88, 722-743.

Font, Y., S. Lallemand, and J. Angelier (1999), Etude de la transition entre l'orogène actif de Taiwan et la subduction des Ryukyu-Apport de la sismicité, Bull. Soc. Géol. Fr., 170, 271-283.

Frepoli, A., G. Selvaggi, C. Chiarabba, and A. Amato (1996), State of stress in the southern Tyrrhenian subduction zone from fault-plane solutions, Geophys. J. Int., 125, 879-891.

Gill, J. B. (1981), Orogenic Andesite and Plate Tectonics, 390 pp., SpringerVerlag, New York.

Hacker, B. R., S. M. Peacock, G. A. Abers, and D. Holloway (2003), Subduction factory: 2. Are intermediate-depth earthquakes in subducting slabs linked to metamorphic dehydration reactions?, J. Geophys. Res., 95, 108(B1), 2030, doi:10.1029/2001JB001129.

Hsu, S.-K., J.-C. Sibuet, and T.-C. Shyu (2001), Magnetic inversion of the East China Sea and Okinawa Trough: Tectonic implications, Tectonophysics, 333, 111-122.

Kao, H., and W.-P. Chen (1991), Earthquakes along the Ryukyu-Kyushu arc: Strain segmentation, lateral compression, and thermomechanical state of the plate interface, J. Geophys. Res., 96, 21,443-21,485.

Kao, H., and R.-J. Rau (1999), Detailed structure of the subducted Philippine Sea plate beneath northeast Taiwan: A new type of double seismic zone, J. Geophys. Res., 104, 1015-1033.
Kao, H., S. J. Shen, and K.-F. Ma (1998), Transition from oblique subduction to collision: Earthquakes in the southernmost Ryukyu arc-Taiwan region, J. Geophys. Res., 103, 7211-7229.

Kao, H., G.-C. Huang, and C.-S. Liu (2000), Transition from oblique subduction to collision in the northern Luzon arc-Taiwan region: Constraints from bathymetry and seismic observations, J. Geophys. Res., 105, 30593079 .

Kelemen, P. B. (1995), Genesis of high Mg \# andesites and the continental crust, Contrib. Mineral. Petrol., 120, 1-19.

Lallemand, S., Y. Font, H. Bijwaard, and H. Kao (2001), New insights on 3-D plates interaction near Taiwan from tomography and tectonic implications, Tectonophysics, 335, 229-253.

Lee, C. S., C.-F. Tsai, S.-L. Chung, and SPOT Members (1998), Active interaction of submarine volcanoes and ocean current in the southernmost Okinawa Trough, Eos Trans. AGU, 79(45), Fall Meet. Suppl., F858.

Lin, J.-Y., S.-K. Hsu, and J.-C. Sibuet (2004), Melting features along the Ryukyu slab tear, beneath the southwestern Okinawa Trough, Geophys. Res. Lett., 31, L19607, doi:10.1029/2004GL020862.

Liu, C.-S., S.-Y. Liu, S. Lallemand, N. Lundberg, and D. L. Reed (1998), Digital elevation model offshore Taiwan and its tectonic implications, TAO, 9, 705-738

Marani, M. P., and T. Trua (2002), Thermal constriction and slab tearing at the origin of a superinflated spreading ridge: Marsili volcano (Tyrrhenian Sea), J. Geophys. Res., 107(B9), 2188, doi:10.1029/2001JB000285.

Menke, W. (1984), Geophysical Data Analysis: Discrete Inverse Theory, 269 pp., Academic, San Diego, Calif.

Nakada, S. (1986), Comparative study of rocks from the Kirishima and Daisen volcanic belts in Kyushu, southwest Japan, Bull. Volcanol. Soc. Jpn., 31, 95-110.

Nakajima, J., T. Matsuzawa, A. Hasegawa, and D. Zhao (2001a), Seismic imaging of arc magmas and fluids under the central part of northeastern Japan, Earth Planet. Sci. Lett., 341, 1-17.

Nakajima, J., T. Matsuzawa, A. Hasegawa, and D. Zhao (2001b), Threedimensional structure of $V_{p}, V_{s}$, and $V_{p} / V_{s}$ beneath northeastern Japan: Implications for arc magmatism and fluids, J. Geophys. Res., 106, $21,843-21,857$

Rau, R.-J., and F. T. Wu (1995), Tomographic imaging of lithospheric structures under Taiwan, Earth Planet. Sci. Lett., 133, 517-532.

Roecker, S. W., Y.-H. Yeh, and Y.-B. Tsai (1987), Three-dimensional $P$ and $S$ wave velocity structures beneath Taiwan: Deep structure beneath an arc-continent collision, J. Geophys. Res., 92, 10,547-10,570.

Rüpke, L. H., J. Phipps Morgan, M. Hort, and J. A. D. Connolly (2004), Serpentine and the subduction zone water cycle, Earth Planet. Sci. Lett., 223, $17-34$

Shinjo, R. (1999), Geochemistry of high Mg andesites and the tectonic evolution of the Okinawa Trough-Ryukyu arc system, Chem. Geol., 157, 69-88.

Shinjo, R., S.-L. Chung, Y. Kato, and M. Kimura (1999), Geochemical and Sr-Nd isotopic characteristics of volcanic rocks from the Okinawa Trough and Ryukyu arc: Implications for the evolution of a young, intracontinental back arc basin, J. Geophys. Res., 104, 10,591-10,608.

Sibuet, J.-C., and S.-K. Hsu (2004), How was Taiwan created?, Tectonophysics, 379, 159-181.

Sibuet, J.-C., B. Deffontaines, S.-K. Hsu, N. Thareau, J.-P. Le Formal, and C.-S. Liu (1998), The southwestern Okinawa Trough back-arc basin: Tectonics and volcanism, J. Geophys. Res., 103, 30,245-30,267.

Sibuet, J.-C., S.-K. Hsu, X. Le Pichon, J.-P. Le Formal, D. Reed, G. Moore, and C.-S. Liu (2002), East Asia plate tectonics since $15 \mathrm{Ma}$ : Constraints from the Taiwan region, Tectonophysics, 344, 103-134.

Stolper, E., and S. Newman (1994), The role of water in the petrogenesis of Mariana trough magmas, Earth Planet. Sci. Lett., 121, 293-325.

Takei, Y. (2002), Effect of pore geometry on $V_{P} / V_{S}$ : From equilibrium geometry to crack, J. Geophys. Res., 107(B2), 2043, doi:10.1029/ 2001JB000522.

Tamura, Y., Y. Tatsumi, D. Zhao, Y. Kido, and H. Shukuno (2002), Hot fingers in the mantle wedge: New insights into magma genesis in subduction zones, Earth Planet. Sci. Lett., 197, 105-116.

Tatsumi, Y. (1986), Formation of the volcanic front in subduction zones, Geophys. Res. Lett., 13, 717-720.

Thurber, C. H. (1983), Earthquake locations and three-dimensional structure in the Coyote Lake area, central California, J. Geophys. Res., 88, $8226-8236$.

Thurber, C. H. (1993), Local earthquake tomography: Velocities and $V_{p} / V_{s}$-theory, in Seismic Tomography: Theory and Practice, edited by H. M. Iyer and K. Hirahara, pp. 563-583, Chapman and Hall, New York. Thurber, C. H., and D. Eberhart-Phillips (1999), Local earthquake tomography with flexible gridding, Comput. Geosci., 25, 809-818.

Tsai, Y.-B. (1986), Seismotectonics of Taiwan, Tectonophysics, 125, 17-37. Um, J., and C. H. Thurber (1987), A fast algorithm for two-point seismic ray tracing, Bull. Seismol. Soc. Am., 77, 972-986. 
Watanabe, T. (1993), Effects of water and melt on seismic velocities and their application to characterization of seismic reflectors, Geophys. Res. Lett., 20, 2933-2936.

Wessel, P., and W. M. F. Smith (1991), Free software helps map and display data, Eos Trans. AGU, 72, 441, 445-446.

Wyss, M., A. Hasegawa, and J. Nakajima (2001), Source and path of magma for volcanoes in the subduction of northeastern Japan, Geophys. Res. Lett., 28, 1819-1822.
Yu, S.-B., H. Y. Chen, and L.-C. Kuo (1997), Velocity field of GPS stations in the Taiwan area, Tectonophysics, 274, 41-59.

S.-K. Hsu, Institute of Geophysics, National Central University, ChungLi 32054, Taiwan. (hsu@oc.gep.ncu.edu.tw)

J.-Y. Lin and J.-C. Sibuet, Ifremer, Centre de Brest, B.P. 70, F-29280 Plouzané Cedex, France. (jylin@ifremer.fr; jcsibuet@ifremer.fr) 